\title{
Strings of Pearls: James, Maupassant, and 'Paste'
}

\author{
Philip Horne (UCL)
}

Les perles composent le collier, mais c'est le fil qui fait le collier. Or, enfiler les perles sans en perdre une seule et toujours tenir son fil de l'autre main, voilà la malice...

[The pearls compose the necklace, but it is the string which makes it a necklace.

Now, to thread the pearls without losing a single one and always to hold one's string with the other hand, there's the trick...]

(Gustave Flaubert, letter To Louise Colet, 26 August 1853) ${ }^{1}$

a case of feeling, of ever so many possible feelings, stretched across the scene like an attached thread on which the pearls of interest are strung

(Henry James, Preface (1908) to The Princess Casamassima $(1886))^{2}$

i À la Maupassant

$1 \quad$ Consulted 23 December 2018 at http://flaubert.univrouen.fr/correspondance/conard/outils/1853.htm

2 Henry James, Literary Criticism: French Writers, Other European Writers, The Prefaces to the New York Edition, edited by Leon Edel and Mark Wilson (New York: Library of America, 1984), p. 1092. (Hereafter LC II.) This essay began as a lecture given on 21 October 2016 at the Third International Conference of the European Society of Jamesian Studies at the American University of Paris, entitled "Reading Henry James in the Twenty-First Century: Heritage and Transmission". I owe particular thanks to Denis Tredy for his extremely helpful 'Teaching the "Grandsons of Balzac" a Lesson: Henry James in the 1890's' (E-rea: Revue électronique d'etudes sur le monde Anglophone, 2.1 (2004)), and to Mary Boyington, for her richly detailed PhD thesis, "«Esprit de Maupassant»: Henry James and French Realism, A Re-evaluation' (Aix-Marseille Université, 2017). Thanks also to Scarlett Baron, Susie Boyt, Annick Duperray, Miranda El-Rayess, Oliver Herford, Neil Rennie, John Scholar. I am grateful as always to Bay James for her kind permission on behalf of the James estate to use unpublished material. 
We are used to Henry James as an ever-critical imitator of his elders - Balzac, Hawthorne, George Eliot, Flaubert, Turgenev - but it's also possible to imitate one's juniors, as James can be seen to have done with Stevenson's Jekyll and Hyde in 'The Turn of the Screw', or Wells's Kipps in 'The Bench of Desolation'. Henry James was seven years older than Guy de Maupassant, yet was in some ways a later developer, and (not least by living longer) went on developing much later - so that for him, we can say, Maupassant is part of the French heritage he made a particularly prominent part of his literary profile - in that, for instance, he began his British career as an interpreter of French literature to Anglo-American culture his first book published in Britain being French Poets and Novelists in 1878. James wrote reviews and essays on French literature from 1865 on; then got to know French writers when he was living and working in Paris for the formative year of 1875-6. It was in this period that he met Maupassant - who was a protégé of Flaubert's - as he recalled in a letter to Edmund Gosse on 15 October 1912.

Distinct to me the memory of a Sunday afternoon at Flaubert's, in the winter of '75-'76, when Maupassant, still inédit [unpublished], but always 'round,' regaled me with a fantastic tale, irreproducible here, of the relations between... two Englishmen, each other, and their monkey! ${ }^{3}$

Maupassant only published his first tale in 1875; it was not until Boule de Suif in 1880 that he came to public attention. James on this occasion was especially

3 Selected Letters of Henry James to Edmund Gosse: A Literary Friendship, edited by Rayburn S. Moore (Baton Rouge and London: Louisiana State University Press, 1988), p. 279. Edmond de Goncourt was also present, and in his journal for 28 February 1875 recorded the young Maupassant's account of a meal with the poet Swinburne and his friend George Powell: 'Une chose m'embêta tout de suite à ce premier déjeuner, c'est que, de temps en temps, Powel branlait un peu son singe, qui s'échappait un peu de ses doigts pour me donner des coups sur la nuque, quand je baissais le cou pour boire.' (Edmond \& Jules de Goncourt, Journal, Tome 2, 1866-1886: Mémoires de la vie littéraire, ed. Robert Ricatte (Paris: Bouquins, 2004), p. 630). My translation: 'One thing annoyed me immediately at this first meal, which was that from time to time Powel would masturbate his monkey a little, and it would escape a little from his grasp to hit me on the neck, when I lowered my head to drink.' 
impressed, or so he recalled for Gosse in 1912, by 'the young Guy's intellectual, critical, vital, experience of the subject-matter' (p.282). ${ }^{4}$

After that, though, as James's Parisian friend Theodore Child, an intimate observer of French literary life, would note in 1892, 'within ten years - 1880 to $1891-$ M. de Maupassant published more than three hundred short tales, and more than twenty volumes, of which six are long novels'. ${ }^{5}$ Maupassant was particularly known for the short stories, and James's admiration from early on is clear. More than once he makes characters in his fiction readers of Maupassant. Susan Stringham in The Wings of the Dove (1902) entertains two passions in life, one being Milly and 'the other one, more imperturbably cerebral, ... for the art of Guy de Maupassant'; while Lambert Strether expects his whole excursion to the country in The Ambassadors (1903) will 'remind him... of Maupassant' - ostensibly through the French driver he'll employ, but perhaps also (for James) anticipating sexual adventures on the river like those that occur in 'Une Partie de Campagne' (1881). ${ }^{6}$ And in 'Flickerbridge' (written 1900, published 1902) the hero guiltily 'recalled something of Maupassant's - the smitten "Miss Harriet" and her tragic fate'.

James's private letters, and notebooks, are dotted with references to Maupassant throughout the 1880s. He wrote to Theodore Child on 30 December 1884 that: 'I read Maupassant, \& dirty \& cynical as he is, he consoles me. C'est un maitre. ${ }^{8}$ And five months later, on 30 May 1885, he told Child, about Bel-Ami (1885), 'I ought already to have thanked you for your friendly thought and delicate attention in

$4 \quad$ Selected Letters of Henry James to Edmund Gosse: A Literary Friendship, edited by Rayburn S. Moore (Baton Rouge and London: Louisiana State University Press, 1988), p. 282.

5 Theodore Child, 'Literary Paris. Second Paper', Harper's New Monthly Magazine (September 1892), 85.508, 489-507, p. 494.

${ }_{6} \quad$ The Wings of the Dove, edited by Millicent Bell (London: Penguin Classics, 2008), VI.4, p. 273; The Ambassadors, edited by Adrian Poole, (London: Penguin Classics, 2008), XI.3, p. 412. 'Flickerbridge', The Better Sort (London: Methuen, 1903), 105-122, p. 117. In 'Miss Harriet' a grotesque English governess kills herself for love in a French village. 8 James to Theodore Child, unpublished MS letter (Virginia MSS 6251-C (Box 2, \#135)) 
sending me Maupassant's ineffable novel, which I fell upon and devoured, with the utmost relish and gratitude. It brightened me up, here, for a day or two, amazingly'. ' On Sunday 11 March 1888, working on 'The Patagonia', he wrote in his Notebooks: 'Oh, spirit of Maupassant come to my aid!'; in February 1889, planning the development of The Tragic Muse, he declared that: 'À la Maupassant must be my constant motto.' On 27 July 1890, sketching a short tale he never wrote, he emphasised to himself, 'The sketch, picture, vision - à la Maupassant.${ }^{10}$ The next year, in February 1891, of 'The Real Thing', seen as a model for other stories:

But in how tremendously few words few words [sic] I must do it. This is a lesson - a magnificent lesson - if I'm to do a good many. Something as admirably compact and selected and concise as Maupassant. ${ }^{11}$

In January 1892, suffering from syphilis, Maupassant attempted to cut his throat; he was committed to an asylum, and suffered from worsening bouts of convulsions till his death in July 1893. James in his notebooks, 30 August 1893:

There are excellent examples of the short novel $-\&$ one that has always struck me as a supremely happy instance is ^poor^ Maupassant's admirable Pierre \& Jean... I want to do something that I can do in three months -

\footnotetext{
$9 \quad$ Henry James Letters, edited by Leon Edel (Cambridge, MA: Belknap Press, 1974-84), 4 vols, III, 91. He does then go on to say it strikes him as 'the history of a Cad, by a Cad - of genius!' (Hereafter HJL III.)

10 The Complete Notebooks of Henry James, edited by Leon Edel and Lyall H. Powers (New York: Oxford University Press, 1987), p. 55. (Hereafter CN.)

$11 \quad C N$, p. 57. In the MS, James crosses out 'and concise' to make it more concise - but not the emphatic doubling of 'few words' (MS Houghton, Journal III). The quotations from James's notebooks in this essay, though references to the 1987 Complete Notebooks are offered for convenience, draw on the text being prepared by Philip Horne, to be published by Cambridge University Press in the Complete Fiction of Henry James vol. 34.
} 
something of the dimensions of Pierre \& Jean. I should be glad also to make my story resemble it in other ways. (CN, pp. 77-8)

'Poor' before 'Maupassant' is inserted as an afterthought, prompted by what might seem a heartless phrase, 'supremely happy' - to the memory of his so-recent, supremely unhappy, human sufferings.

James would again recall the late French master on 26 June 1895 when planning 'a little tale that Maupassant would have called Les Lunettes, though I'm afraid The Spectacles won't do' (CN, p. 125); it became Glasses (1896). And on 5 October 1899 James tells himself that 'The Tree of Knowledge' would be 'Practicable on the rigid Maupassant (at extremest brevity) system' (CN, p. 184).

ii Paste': transposing the terms

This brings us to - or just past - the moment of 'Paste', a short story directly based on Maupassant. On 7 August 1899 James wrote to his agent Pinker that 'I am sending Colles tomorrow the short tale -5000 words - as to which you arranged a

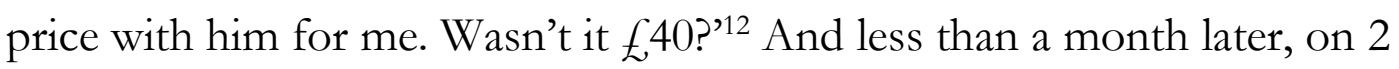
September 1899: 'I acknowledge with thanks the receipt from you today of your cheque for 47.5 .0 - my fee, less your commission, for my tale of "Paste", supplied to the Author's [sic] Syndicate... ${ }^{13}$

'Paste' saw the light, through Colles, in Frank Leslie's Popular Monthly, in the U.S., in December 1899 - the Christmas number: 'Paste' is sandwiched between 'Miss

\footnotetext{
12 Unpublished MS letter to James Brand Pinker, 7 August 1899 (Beinecke, Za James 1, Vol. 1).

13 Unpublished MS letter to James Brand Pinker, 2 September 1899 (Beinecke, Za James 1, Vol. 1). (William Morris Colles (1865-1926), an English literary agent, founded and was managing director of the Authors' Syndicate.)
} 
Mason's Christmas Dinner' by the pious Margaret E. Sangster and 'The OldFashioned Christmas Dinner' by the popular Michigan poet Will Carleton, so might have been expected to be a Christmas story. It does certainly involve gifts and shopping. And as we approach the (revised) text in Volume XVI (1908) of the New York Edition, the relation to Maupassant is signposted for us. The Preface sets it up, declaring a fairly simple intertextual relation:

The origin of "Paste" ... was to consist but of the ingenious thought of transposing the terms of one of Guy de Maupassant's admirable contes. In "La Parure" a poor young woman, under 'social' stress, the need of making an appearance on an important occasion, borrows from an old school friend, now much richer than herself, a pearl necklace which she has the appalling misfortune to lose by some mischance never afterwards cleared up. Her life and her pride, as well as her husband's with them, become subject, from the hour of the awful accident, to the redemption of their debt; which, effort by effort, sacrifice by sacrifice, franc by franc, with specious pretexts, excuses, a rage of desperate explanation of their failure to restore the missing object, they finally obliterate — all to find that their whole consciousness and life have been convulsed and deformed in vain, that the pearls were but highly artful 'imitation' and that their passionate penance has ruined them for nothing. (LC II, pp. 1242-3) ${ }^{14}$

'La Parure' first appeared on the $17^{\text {th }}$ of February 1884 in Le Gaulois. Here is its last moment, to give the flavour of Maupassant's final bleak twist:

14 The 'pearls' James refers to here are actually diamonds - on which more later. 
Mme Forestier, fort émue, lui prit les deux mains.

- Oh! ma pauvre Mathilde! Mais la mienne était fausse. Elle valait au plus cinq cents francs!... 15

(They've paid back eighty times these 500 francs: forty thousand.) In the translation by James's friend Jonathan Sturges, which appeared in 1889 and which James almost certainly ran an eye over, since he furnished the introduction:

Mme. Forestier, strongly moved, took her two hands.

'Oh, my poor Mathilde! Why, my necklace was paste. It was worth at most five hundred francs!'16

The story certainly made an impression on James - and seemingly too the emphasis this translation puts on the word 'paste'. ${ }^{17}$ The Preface goes on, producing a playfully elaborate chiasmus:

It seemed harmless sport simply to turn that situation round-to shift, in other words, the ground of the horrid mistake, making this a matter not of a false treasure supposed to be true and precious, but of a real treasure supposed to be false and hollow: though a new little "drama," a new setting for my pearls — and as different as possible from the other-had of course withal to be found. (p. 1243)

15 Guy de Maupassant, 'La Parure', Contes et Nouvelles, ed. Louis Forestier (Paris: Gallimard: Bibliothèque de la Pléiade, 1974), 2 vols, I, 1198-1206, p. 1206.

16 The Odd Number: Thirteen Tales by Guy De Maupassant, translated by Jonathan Sturges, with an Introduction by Henry James (New York: Harper \& Brothers, 1889), p. 70.

$17 \quad$ This use and that in the story's title refer to the OED's sense 8 of 'paste': 'Heavy, very clear flint glass used for making imitation gems; an imitation gem or (collectively) imitation gems made of this.' 
How 'ingenious' is this 'thought', and how 'simply' can we understand it - to take up James's own terms? ${ }^{18}$ And the question arises: what is 'The Story in It'? - to take the title of an ironic tale, on the germane subject of French fiction and English moral hypocrisy, that James had written by 27 February 1900, within six months of 'Paste'.

James's tale starts in a different enough 'setting' from Maupassant's Paris - in a rural English vicarage with a poor girl, a governess, Charlotte Prime, niece of the vicar and his wife, who have died in quick succession. The vicar's son, and the aunt's stepson, is Arthur Prime, a sanctimonious lawyer, whose name seems to imply primogeniture, the official line, the law, and who has come down from town to take charge. At any rate he seems in possession and reluctant to give Charlotte any memento of her beloved aunt. But he seems embarrassed about the dead woman's - his stepmother's - theatrical past: she was an actress before marrying his father. He offers Charlotte, as a memento 'Of your poor dead aunt who was so kind to you,' as he puts it 'with virtuous sternness', a tinful of stage jewellery (though he's too mean to offer her the tin itself): ${ }^{19}$

They were too dreadfully good to be true, for her aunt had had no jewels to speak of, and these were coronets and girdles, diamonds, rubies and sapphires. Flagrant tinsel and glass, they looked strangely vulgar, but if after the first queer shock of them she found herself taking them up, it was for the very proof, never yet so distinct to her, of a far-off faded story. (p. 64)

18 One might also sense an echo of 'La Parure' and its picture of a life of grinding poverty in James's last published tale, 'The Bench of Desolation' (1909-10), where Herbert Dodd's debt of $f 400$ (perhaps recalling the 40,000 francs?), demanded as settlement of a potential breach of promise case by his fiancée Kate Cookham, turns out by a different twist to have been equally arbitrary or unnecessary.

19 Henry James, 'Paste', The Soft Side (London: Methuen, 1900), 63-84, p. 66. 
They're objects that tell a story, then - but, this being James, they're 'ambiguous objects' (p. 74) and it's an ambiguous story. They were found in an obscure corner - but Arthur insists they were 'lost' and 'forgotten' (pp. 66, 67) - not hidden.

In a bag in the tin our heroine Charlotte finds

a necklace of large pearls, such as might once have graced the neck of a provincial Ophelia and borne company to a flaxen wig (p. 68). ${ }^{20}$

Charlotte wonders if these might be 'worth something'. But Arthur feels them, and despite their weight announces, 'Worth at most thirty shillings'.

'Besides,' he lucidly inquired, 'how could she ever have come by them?'

'Mightn't they have been a present?'

Arthur stared at the question as if it were almost improper. 'Because actresses are exposed-?' He pulled up, however, not saying to what, and before she could supply the deficiency had, with the sharp ejaculation of 'No, they mightn't!' turned his back on her and walked away. (p. 69)

If real, in other words, they're so valuable they would have had to be a gift from a lover - which is unthinkable. For if they are genuine, the stepmother was false unchaste, improper, intolerable. The possibility has to be foreclosed.

20 In the New York Edition 'necklace' becomes 'string, and 'such as' becomes 'such a shining circle as' (XVI, p. 320). (Hereafter NYE.) There's a Shakespearian story to the vicar's marriage: 'An honest widowed cleric with a small son and a large sense of Shakspeare had, on a brave latitude of habit as well as of taste-since it implied his having in very fact dropped deep into the "pit" - conceived for an obscure actress, several years older than himself, an admiration of which the prompt offer of his reverend name and hortatory hand was the sufficiently candid sign' (p. 64). 
'No, they mightn't!' appears to be the last word. Properly rebuked as 'almost improper', Charlotte takes them away, back to her miserable post as a governess. There's a house party at her employer's, and a visitor arrives, 'a strange, charming little red-haired, black-dressed woman, with the face of a baby and the authority of a commodore' (p. 71). Mrs Guy specialises in organising tableaux vivants for the aristocracy (these, too, in a way, striking fakes or reproductions of brilliant originals), and Charlotte offers to loan her the costume jewellery. The woman is struck by the pearls - as a connoisseur declares them real - and wants them; so the honest Charlotte tells her she'll have to deal with Cousin Arthur, who has chambers in the Temple. The woman loves them partly for the sake of the aura of sexual passion that to her they eloquently carry:

'I'm dying for them. There's a special charm in them-I don't know what it is: they tell so their history.'

'But what do you know of that?'

'Just what they themselves say. It's all in them—and it comes out. They breathe a tenderness - they have the white glow of it. My dear,' hissed Mrs. Guy in supreme confidence and as she buttoned her glove- 'they're things of love!'

“Oh!" our young woman vaguely exclaimed.

"They're things of passion!"

"Mercy!" she gasped, turning short off. (p. 80)

'Paste' is in one aspect what we could call a thing-fiction, then - a story told through the vicissitudes of an object. The pearls in it are alive - they have a past. Charlotte now feels she has no choice but to take them back to Arthur, who gave them to her as worthless fakes. But at the news that they are thought real he is 'disagreeably affected' and insists on denying the 'beastly unpleasant imputation' (p. 
82). Even so, he will take them to experts for valuation, he says - and locks them in a drawer.

'And if the people say they're real—?'

He hesitated - then had his strangest manner. 'They won't say it! They shan't!' (p. 83)

She leaves - without the pearls. Is the story over?

No, James has a twist. Charlotte, back at her employer's in Eaton Square, meets her grand baby-faced friend Mrs Guy wearing 'a lovely necklace’ (p. 83). Comments Charlotte,

'They're almost as fine as Arthur's.'

'Almost? Where, my dear, are your eyes? They are "Arthur's"!' After which, to meet the flood of crimson that accompanied her young friend's start: 'I tracked them—after your folly, and, by miraculous luck, recognised them in the Bond Street window to which he had disposed of them.'

'Disposed of them?' the girl gasped. 'He wrote me that I had insulted his mother and that the people had shown him he was right—had pronounced them utter paste.'

Mrs. Guy gave a stare. 'Ah, I told you he wouldn't bear it! No. But I had, I assure you,' she wound up, 'to drive my bargain!' (pp. 83-4)

That is, Arthur has lied to Charlotte, rubbing the salt of insult into the wound of injury - and has pocketed the proceeds to boot. And Mrs Guy has had to pay a good deal on top to the Bond Street jeweller. 
This is not quite the end of the story, but it makes clear that the turn is indeed that the pearls are a 'real treasure', not false - implying a hidden grand passion. Quod erat demonstrandum, according to the Preface. Or at least, their 'reality' as pearls is attested by an exchange involving money, with whatever reality that can guarantee. But there are further differences from 'La Parure' - where, for instance, there's no (direct) issue of sexual misconduct.

\section{ii. 'And pearls are so easily imitated.' 21}

James seems disingenuous in the Preface in saying his process was 'simply to turn that situation [in 'La Parure'] round' - or at least, his memory has seriously betrayed him. For, as has been known since at least 1964 and T.M Segnitz's article 'The Actual Genesis of Henry James's "Paste", there's another Maupassant tale in the background here - 'Les Bijoux' (Contes et Nouvelles I, 764-71) - an earlier, related tale first published in Gil Blas on 27 March 1883. The twist is that when Maupassant wrote 'La Parure' he himself was ironically reversing the premises of 'Les Bijoux', less than a year later. ${ }^{22}$

To look at 'Les Bijoux' beside 'Paste', in fact, and in the light of HJ's simplifying Preface, is mildly shocking - 'Paste' is much closer to it in numerous respects than to 'La Parure', the declared inspiration. In 'Les Bijoux' the husband is a poor clerk: James's is a poor cleric. His beautiful, much-loved wife goes to the theatre as a spectator, supposedly with female friends: the dead woman in James has performed at the theatre.

\footnotetext{
$21 \quad$ 'Paste', p. 69.

22 The action of 'Les Bijoux' happens after 20 July 1876 in rue des Martyrs, the same street where the couple live in 'La Parure' - a neighbouring story in more than one way.
} 
The stage-struck wife in 'Les Bijoux' develops the habit of dressing up - she wears costume jewellery - she acquires pieces all the time, a hoard like that in 'Paste'. The husband adores her. Suddenly, she dies of a fever. After his initial grief, the husband discovers how good she must have been at household economy - because he quickly runs out of money. Desperate, he decides to see how much he can get for some of the better fake jewellery she has left. (It's a collection kept in a box, as in 'Paste', where Arthur won't even give Charlotte the tin.) At the jeweller's shop in the Rue de la Paix (in 'Paste' it's Bond Street, the London equivalent) he discovers it's not after all fake - is very valuable - and must have been a gift - but from whom? And given in return for what favours received?

Il s'efforçait de raisonner, de comprendre. Sa femme n'avait pu acheter un objet d'une pareille valeur. - Non, certes. - Mais alors, c'était un cadeau! Un cadeau! Un cadeau de qui? Pourquoi?

Il s'était arrêté, et il demeurait debout au milieu de l'avenue. Le doute horrible l'effleura. - Elle? - Mais alors tous les autres bijoux étaient aussi des cadeaux! Il lui sembla que la terre remuait; qu'un arbre, devant lui, s'abattait; il étendit les bras et s'écroula, privé de sentiment. (Contes et Nouvelles I, p. 768)

He struggled to reason, to understand. His wife couldn't have bought an object of such value. - No, certainly. - But then, it must have been a gift! A gift! A gift from whom? Why?

He had stopped, and he remained standing there in the middle of the avenue. The horrible doubt brushed him. - Her? - But then all the other jewels were presents too! It seemed to him that the earth was moving; that a tree, in front of him, was crashing down; he stretched out his arms and collapsed, unconscious. [My translation] 
He swoons then - but recovers; reflects; sells all the jewels; then retires from the office on the considerable proceeds. Six months later, however, he remarries, this time to the opposite of his wife: a woman who is honest, but who makes him miserable: 'Elle le fit beaucoup souffrir.' [She made him suffer terribly] (Contes et Nowvelles I, p. 771).

Regarding Lantin in the street with his 'horrible doubt', we can hardly help recalling the equivalent moment in 'Paste': "Mightn't they have been a present?" and Arthur's 'sharp' denial of the possibility. 'Non, certes.' And in both 'Paste' and 'Les Bijoux' after the woman's death the value of a marriage is thrown into question by the genuineness of a boxful of apparently fake jewels (not a single piece, as in 'La Parure' - though it boils down to a single piece in 'Paste' - perhaps to suggest one intense passion rather than a promiscuous multitude). In both the discovery of the true value of the jewels occurs through their valuation at a jeweller's in the capital. Both Lantin and Charlotte Prime are more or less penniless, so that the value of the jewels means a good deal to them. Mme Lantin is twice mentioned as wearing or handling 'les colliers de perles fausses' or 'les colliers de perles', pearl or fake-pearl necklaces (p. 765) - which makes 'Les Bijoux' seem a possible source for James's memory in the Preface that the heroine of ' $\mathrm{La}$ Parure' loses 'a pearl necklace'. In 'La Parure' itself, the heroine precisely turns down the loan of 'un collier de perles', 'a pearl necklace', for that of 'une superbe rivière de diamants' (p. 1201), 'a superb diamond necklace' - which is what she actually loses.

Have we caught James red-handed in not only denying what is an act of pretty direct trans-cultural borrowing, like some Hollywood producer ripping off a foreign hit without paying for the rights - but claiming credit for an 'ingenious thought' for which no credit is really due to him?? Is he just being sly, covering his tracks as a picker and chooser of others' subjects? It's incriminating that James 
apparently didn't own Contes du Jour et de la Nuit (1885), the collection in which 'La Parure' appeared, but he did own Clair de Lune (1883), in which 'Les Bijoux' was collected. ${ }^{23}$

However, there are mitigating circumstances. It doesn't for one critic at least seem to be a case of simple theft. The awkward fact that this reversal had already been done by Maupassant and resulted in 'La Parure' is noted in Richard Fusco's 1994 Maupassant and the American Short Story: The Influence of Form at the Turn of the Century, which deals interestingly with James. Can James be in the clear? For Fusco concludes, rather breathtakingly, 'I see no evidence that [James] remembered ['Les Bijoux'] when he composed "Paste". 24

It may not have been a fully conscious memory, perhaps. In James's 1888 essay on Maupassant, of which more in a moment, he lists many stories by the French author - but neither 'La Parure' nor 'Les Bijoux'. He does however name - among Maupassant's 'little perfections' - a story called 'Le Collier', which means 'The Necklace' (the English title James's friend Sturges gives his translation of 'La Parure'). But 'Le Collier' appears nowhere in the Pléiade two-volume edition of Maupassant's Contes et Nowvelles. The confusion of title may well have meant that James somehow recalled the two stories as one - in a palimpsestic way which was creative for him, and is intriguing for us.

iii 'A long Maupassant'

23 See Leon Edel \& Adeline Tintner, The Library of Henry James (Ann Arbor, MI: UMI Research Press, 1987), p. 48.

24 Richard Fusco, Maupassant and the American Short Story: The Influence of Form at the Turn of the Century, (University Park, PA: Penn State UP, 1994), p. 202. 
Eleven years before 'Paste', James's essay 'Guy De Maupassant' came out in the Fortnightly Review for March 1888. James to Theodore Child, 27 March [1888]:

I wrote a long Maupassant for the March number [of the Fortnightly Revien] and received but $£^{23}$ for it. I think they have only one price - and I have no art whatever of haggling for terms. It's beyond me - and I can't do it. (HJL III, p. 229)

This essay, of nearly 12,000 words, is partly a continuation of the argument of his essay 'The Art of Fiction' of 1884 - especially the plea for the freedom of the novel as a form, reiterated at a cultural moment when it seems threatened by a moral and legal backlash against the liberties taken by the French as exemplified by Zola and his English publisher Henry Vizetelly. James was tangentially caught up in the controversy not only as a critic of Zola, but because Vizetelly had included two pages of James's Nana review as a 'Prefatory Note' - presumably without permission - in his edition of Nana in March 1884, and Nana was a prime exhibit in the prosecutions of Zola for indecency. ${ }^{25}$

The 1888 essay sees in Maupassant's work 'an essential hardness — hardness of form, hardness of nature'. In questions of 'form' hardness is good, but in those of 'nature' less sympathetic, less admirable - though James does see a capacity for tenderness in places (and will come to see it as Maupassant's direction of travel). And James comments that

25 James's works in the 1880s bore some traces of Zola's influence, even if ironically refined: for The Princess Casamassima, he told Perry on December 12, 1884, 'I have been all the morning at Millbank Prison (horrible place) collecting notes for a fiction scene. You see I am quite the Naturalist' (HJL III 61). 
His vision of the world is for the most part a vision of ugliness, and even when it is not, there is in his easy power to generalise a certain absence of love, a sort of bird's-eye-view contempt. ${ }^{26}$

One can see James as looking back to this long 1888 essay in a number of respects when he writes 'Paste'. - as if he is consciously overlapping with, inhabiting or inflecting, the world of Maupassant through more than a single source-text. And it's simultaneously an bommage and a corrective - and perhaps a continuation of Maupassant's trajectory. He describes Maupassant's habitual approach:

The author fixes a hard eye on some small spot of human life, usually some ugly, dreary, shabby, sordid one, takes up the particle, and squeezes it either till it grimaces or till it bleeds. (LC II, p. 536)

The ugly room where the aunt's body is laid out in 'Paste' isn't exactly a sordid spot, but it is described vividly and unattractively as 'the great cold chamber of hospitality, the dampish greenish room where visitors slept' (p. 63; 'dampish greenish' might seem to imply mouldiness). And in particular James's essay comments on ugly disputes about inheritance - like the one in 'Paste':

No one gives us like M. de Maupassant the odious words exchanged on such an occasion as that: no one depicts with so just a hand the feelings of small people about small things. (LC II, p. 541)

26 James, Henry, 'Guy de Maupassant', Literary Criticism: French Writers, Other European Writers, The Prefaces to the New York Edition, edited by Leon Edel and Mark Wilson (New York: Library of America, 1984), 521-49, pp. 526-7. (Hereafter LC II.) This powerfully contrasts with 'The Lesson of Balzac' in 1905, where James declares of the author of the Comédie Humaine that 'It was by loving [his characters]... - that he knew them' (LC II, p. 132). 
James has a try at such moral ugliness in 'Paste', though, with the clammily hypocritical Arthur - with his insistence, for example, that 'They're what I originally said they were. They're rotten paste' (p. 82).

Beyond such general correspondences - shabbiness, family disputes - some more particular echoes make the 1888 essay, or at least the same concerns, seem to have been on James's mind when he wrote 'Paste'. For convenience, I'll number them.

1) One of Maupassant's most recent works when James wrote the essay was 'Le Roman' (1888), a manifesto about fiction which Maupassant insisted was not (as James nonetheless called it) a Preface to Pierre et Jean, which it preceded in the same volume. We've seen that James's title for his tale could be seen as echoing the devastating close of 'La Parure' in Sturges's translation ('my necklace was paste'); but it could also be read as harking back to a quotation from Maupassant that occurs in the 1888 essay. The passage comes from 'Le Roman':

Quand nous lisons, nous, si saturés d'écriture française que notre corps entier nous donne l'impression d'être une pâte faite avec des mots, trouvons-nous jamais une ligne, une pensée qui ne nous soit familière, dont nous n'ayons eu, au moins, le confus pressentiment? ${ }^{27}$

James's own translation:

When we read, so saturated with French writing as we are that our whole body gives us the impression of being a paste made of words, do we ever find a line, a thought, which is not familiar to us, and of which we have not had at least a confused presentiment? (LC II, p. 533)

27 'Le Roman', Pierre et Jean (1888), ed. Bernard Pingaud (Paris: Folio Classique, 1982; repr. 2012), p. 59. 
'A paste made of words': this might be read as a description of the inescapable condition of intertextuality, and perhaps also of the related condition of belatedness - the sense that all the stories have been told, all the veins exhausted, so that apparent novelties are always echoes. We might indeed apply this to 'Paste' in its borrowings or adoptions from 'Les Bijoux' - which then gives us perhaps a 'confus pressentiment' of 'Paste' - or 'Paste' gives us 'un confus souvenir' of 'Les Bijoux'. But 'Paste' seems a highly wrought work, as well as one in which what James calls (after his brother William James) 'unconscious cerebration' has played its part, and embodied in it is not only a sense of familiar elements being reworked, but also an awareness of the differences made by a new sensibility.

The word 'paste', moreover, James's title, is one of those words that can mean a thing and its opposite, like 'cleave' or 'fast' - it's perhaps a case of what Freud calls 'The Antithetical Meaning of Primal Words' (1924). ${ }^{28}$ It means imitation, fake; but it also has a meaning, questionably declared obsolete by the Oxford English Dictionary: '7. The material of which a person is regarded as made, seen as an indication of character or personality. Cf. mettle, stuff.' 29 'Paste' in this sense (true nature) occurs more than once in James: 'he was of so soft and fine a paste' (The Bostonians); 'of an admirable fine paste' (Preface to The Spoils of Poynton); 'of the same moral paste' (The Golden Bowl); 'the very different personal paste' ('The Author of "Beltraffio"”); and in 'A New England Winter', of Rachel Torrance,

28 Sigmund Freud, 'The Antithetical Meaning of Primal Words' (1910), The Standard Edition of the Complete Psychological Works of Sigmund Freud: Five Lectures on Psycho-Analysis, Leonardo da Vinci and Other Works, (London; Hogarth Press, 1953-74), 24 vols, Volume XI, 153-162.

29 The OED's two most modern examples both involve figures important to James: '1863 M. Arnold in Cornbill Mag. Aug. 244 To us... with the German paste in our composition. / 1874 tr. Balzac Droll Stories ii. 256 The Marchesa... consented... for the pleasure of knowing of what paste God made kings.' 
where 'Rachel was not of an insipid paste'. ${ }^{30}$ This makes us think of the way the action of the story reveals the reality, the true stuff of which the characters are made - Charlotte's honesty and sympathetic imagination, Arthur's unctuous hypocrisy, Mrs Guy's desires and unscrupulousness.

2) One element in 'Paste' might be taken as an oblique approach to the predicament of belatedness sketched by Maupassant in 'Le Roman'. The old pearls come to glow with life - when Mrs Guy wears them. Charlotte demands,

"What in the world have you done to them?"

"Only handled them, understood them, admired them and put them on. That's what pearls want; they want to be worn-it wakes them up. They're alive, don't you see? How bave these been treated? They must have been buried, ignored, despised. They were half dead. Don't you know about pearls?" (p. 74)

We may not particularly 'know about pearls', but a little investigation tells us that, when worn, pearls indeed do take on a lustre from the oils of the skin, and the skin from the nacreous lustre of pearls. In Nathaniel Parker Willis's 1839 American verse-play Dying to Keep Him; Or, Tortesa the Usurer, praised by Poe, such an interchange and mutual enrichment seems implicit in the painter Angelo's comment to his beautiful subject Isabella:

$30 \quad$ The Bostonians, ed. Richard Lansdown (London: Penguin Classics, 2000), p. 240 (Ch. 32); Literary Criticism: French Writers, Other European Writers, The Prefaces to the New York Edition, p. 1148; The Golden Bowl, ed. Ruth Bernard Yeazell (Penguin Classics, 2009), p. 253 (Book III, Ch.V); 'The Author of "Beltraffio", Stories Revived: First Series (London: Macmillan 1885), p. 23 reads 'a very different paste'; the NYE (XVI p. 26) revises this to the phrase cited; 'A New England Winter', Tales of Three Cities (London: Macmillan 1884), p. 174 (Ch. V). The word also implies malleability: 'Ibsen kneads the soul of man like a paste' ('On the Occasion of Hedda Gabler', Essays in London and Elsewhere (London 1893), 241-47, p. 243). 
If you'll forgive me, I'll observe an instant,

How the bright blood and the transparent pearl

Melt to each other! ${ }^{31}$

The way 'half dead' pearls can be revived may also be, more allegorically, an emblem of literary transmission - to be newly possessed brings them back to life. And 'They want to be worn - it wakes them up' might apply to the way Maupassant's story (or stories) have seemed to James to demand rewriting reawakening in a new context, a new setting.

3) The germ of the plot of 'Paste' is in the 1888 essay too: in a parenthetical aside on the heroine of Maupassant's 1883 novel Une Vie James says:

(it costs her apparently as little as may be in the way of a shock, a complication of feeling, to discover, by letters, after her mother's death, that this lady has not been the virtuous woman she has supposed). (LC II, p. 545)

In fact James drastically misrepresents the impact of the discovery on Jeanne:

Et soudain, la tête éperdue, elle rejeta d'une secousse ces papiers infâmes, comme elle eût rejeté quelque bête venimeuse montée sur elle, et elle courut à la fenêtre, et elle se mit à pleurer affreusement avec des cris involontaires qui lui déchiraient la gorge; puis, tout son être se brisant, elle s'affaissa au 
pied de la muraille, et, cachant son visage pour qu'on n'entendît point ses gémissements, elle sanglota, abîmée dans un désespoir insondable. ${ }^{32}$

And suddenly, losing her head, she violently shoved away those hateful papers, as she would have pushed away some poisonous beast that was on top of her, and she ran to the window, and started to weep dreadfully, with involuntary cries that lacerated her throat; then, as her whole being fell into pieces, she collapsed at the foot of the wall, and, hiding her face so no one would hear her groans, she sobbed, plunged in abysmal despair. [My translation]

This extremity of emotional violence may not exactly qualify as a 'complication of feeling', perhaps, but surely it is not 'as little as may be in the way of a shock'. Such a misrepresentation, whatever its source, we can say at least clears space for James to make his own contribution, and he makes such a discovery, for Charlotte, in contrast, about her aunt, exactly 'a shock' and a serious 'complication of feeling' a true 'complication' and ambivalence, a moral quandary. And James may be mentioning this here implicitly to mark the distance travelled by Maupassant from Une Vie (1883) to Pierre et Jean, four years later, where James knew very well that suspecting and discovering a mother's infidelity becomes indeed a traumatic and sustained preoccupation for one of Maupassant's main characters, in fact the core of the entire novel.

4) The pearl necklace in James's tale is described as Guy de Maupassant, Une Vie, edited by Pierre Cogny (Paris: Garnier-Flammarion, 1974),
p. 157 (Ch. IX). 
the only ornament, surely, in all the late Mrs. Prime's_-the effaced Miss Bradshaw's-collection, in the least qualified to raise a question. (p. 74)

The late actress and vicar's wife is indeed three times called 'the effaced Miss Bradshaw'. Why this name? ${ }^{33}$ In James's Maupassant essay his subject's form of realism is compared to the railway guide which also bears it:

his effort has been to give the uncomposed, unrounded look of life, with its accidents, its broken rhythm, its queer resemblance to the famous description of "Bradshaw" - a compound of trains that start but don't arrive, and trains that arrive but don't start. (LC II p. 544) (4 $^{34}$

The brevity of the journey upon which the short story in particular, Maupassant's distinguishing form of output, takes us means we get beginnings or endings, but seldom the whole story; and James resorts again to an ornamented variation on chiasmus (trains that start but don't arrive, and trains that arrive but don't start), an existing joke which he turns to serious account as a way of evoking life's inconclusiveness, or its mysterious origins, apparently looking back to 'The Art of Fiction' and 'the very note and trick, the strange irregular rhythm of life'. 'The effaced Miss Bradshaw', the actress with a past, is lost in the vicar's wife, but then even more removed by being dead before James's story begins: we see neither the beginning nor the end of her journey - only getting the sense of it as it haunts the

33 James only once before or after used the name for a character - an incidental one, mentioned once only, and that was in 'A Most Extraordinary Case' (1868), before he came to Europe.

34 James is recalling a comic play in Punch called Bradshaw: A Mystery (1856), about two harassed lovers who are separated then reunited: Leonora laments 'Bradshaw has nearly maddened me' and Orlando replies: 'And me. / He talks of trains arriving that ne'er start; Of trains that seem to start, and ne'er arrive' (Charles Larcom Graves, Mr. Punch's History of Modern England: Vol. 1: 1841-1857 (London: Cassell \& Co., 1921), 4 vols., I, p. 71). 
present action. Our heroine Charlotte is impelled to acts of responsive imagination, of heightened sensibility, in her state of obsessive identification with her aunt:

The little governess at Bleet put on the necklace now in secret sessions; she wore it sometimes under her dress; she came to feel, verily, a haunting passion for it. (p. 81)

This undersense informs the tale. 'The pearl is the unwritten', laments the dying author Dencombe in 'The Middle Years' (1893), and one might apply the thought to the original recipient of the pearls in 'Paste', whose story never is written but haunts us. ${ }^{35}$

5) Charlotte, in fact, has a capacity for reflection and quiet passion which corresponds to part of James's more general critique of Maupassant in the 1888 essay: he is a master of form - but his form is thinning, reductive. His gemlike brevity corresponds to a cynicism that says we regularly know what to think of human motives, types, etc. - so there's no need to dally or haver.

M. de Maupassant has simply skipped the whole reflective part of his men and women - that reflective part which governs conduct and produces character. (LC II, p. 547)

It is emphasised in 'Paste' that Charlotte is reflective (for instance, 'she was to have a long recall of the scene' (p. 82)): 'I must think', she insists three times: 
'Well, I must think. Why didn't she sell them?' Charlotte broke out in her trouble.

Mrs. Guy had an instant answer. 'Doesn't that prove what they secretly recalled to her? You've only to be silent!' she ardently repeated. 'I must think-I must think!' (pp. 77-8)

'I must think-I must think!' That Maupassant 'has simply skipped the whole reflective part' may be true enough of 'La Parure', where sheer necessity drives the action and reflection and regret at the waste of life appear only as implications of the twist at the end. But it's not true of Pierre et Jean, as James acknowledges in the 1888 essay. That great short novel appears - as part of the progress I mentioned earlier, hailed by Theodore Child as a late 'evolution towards kindness and humanity' - to be moving in the direction of what 'Le Roman' calls 'l'analyse', if not 'l'analyse pure', of reflection and a richer sense of character, albeit with a characteristic hard edge. ${ }^{36}$ That trajectory was not apparent to all.

Half a year after James's Maupassant essay, the agitation against Vizetelly and the French would culminate in the prosecution of the former in the autumn of 1888 for obscene libel in his translations of Zola, and he was prosecuted again on 1 May 1889 , as the next day's Times tells us - through the agitations of the National Vigilance Association. On that date the prosecution at the Bow-Street magistrates' court charged Messrs. Vizetelly and Co. with publishing seven novels by Zola, and also “'A Woman's Life,” by Guy de Maupassant, and “A Ladies” Man," by the same author' (Maupassant's Une Vie and Bel-Ami); passages in the latter were singled out in court as 'obscene'. And the judge, Mr Vaughan, said 'He had read the passages in the books, and had never read anything more 
demoralizing.' ${ }^{37}$ Thus by the time a further essay by James on Maupassant came out - the second of his two - in the October of 1889, as the Introduction to Sturges's The Odd Number: Thirteen Tales by Guy De Maupassant, the subject had become very delicate - that is, indelicate, less speakable, a target for xenophobic feeling. ${ }^{38}$

James seems stirred to resistance by the manifestation of intolerance, coming to the defence of his French colleague, even in the area - 'the whole reflective part' where he had found him wanting the year before. For Theodore Child and James, Maupassant's work seemed to be evolving in an admirable direction. Child would write sympathetically (in an unexplained past tense) in an article on 'Literary Paris' in Harper's New Monthly Magazine in September 1892 of how Maupassant had in his later works shown an increasing 'spirit of fraternity, and even of compassion, that is not far from the well-spring of human tears', and of his 'evolution towards kindness and humanity'. ${ }^{39}$ And a move to reflection is identified by James as a new tendency in Maupassant in his 1889 introduction to The Odd Number. He had in 1888 recognised Pierre et Jean, he says, as, 'so far as my judgment goes, a faultless production', detecting 'something touching in Mme. Roland's âme tendre de caissière, as exhibited in Pierre et Jean' (LC II, p. 542) and seeing the embittered elder brother Pierre as 'one of the few instances of operative character' - character determining destiny - in Maupassant's oeuvre (LC II, p. 546). In the Sturges introduction he

37 Anon., 'Police', The Times, London, Thursday, 2 May 1889, p. 3.

38 The essay also appeared on 19 October 1889 in Harper's Weekly.

39 Theodore Child, 'Literary Paris. Second Paper', Harper's New Monthly Magazine

(September 1892), 85.508, 489-507, p. 495. (This view only partly coincides with that in an 1894 essay by Tolstoy, which argues that Maupassant starts to emancipate himself as early as Une Vie (1883) from his corrupting milieu, but then, tempted by success into overproduction, succumbs to it again in his novels, so that it is 'in the best of [his short stories] that we see how the moral feeling grew in the author' ('The Works of Guy de Maupassant' (1894) (translated by Leo Wiener, 1905), The Complete Works of Count Tolstoy (London: J.M. Dent, 1920), 24 vols, XX: consulted 25 August 2018 at

https://en.wikisource.org/wiki/The Works of Guy de Maupassant). 
writes of Maupassant's new novel of 1889, Fort Comme la Mort, as consolidating the tendency he had identified: towards the analysis of

shades of feeling and delicacies of experience to which he had shown himself rather a stranger. They are the work of an older man, and of a man who has achieved the feat of keeping his talent fresh when other elements have turned stale (LC II, p. 554).

James's view of Pierre et Jean, which becomes for him a talismanic text, deserves a moment's attention, so forcefully and exemplarily does it strike him. It may have served as a model for 'The Turn of the Screw', and perhaps less happily The Sacred Fount - but also for The Golden Bowl: formally controlled stories of growing suspicion where the limitations of point of view yield intensity and ambiguity, and thus suspense. It has a simple enough plot: Jean, the younger of two adult sons of a moderately successful jeweller, M. Roland, and his wife, who have retired from Paris to Le Havre, receives an unexpected large inheritance from a family friend who has died. His elder brother Pierre, through whom the narration is mainly concentrated, first feels twinges of jealousy - then increasingly wonders why such a large sum has been left to one brother alone, coming to suspect with Hamlet-like horror that his parents' kindly bachelor friend Maréchal has had an affair with his mother and that Jean is the issue. He becomes increasingly alienated and isolated by these thoughts. Pierre and his mother come to regard each other with mutual suspicion:

On eût dit qu'ils s'épiaient, qu'une lutte venait de se déclarer entre eux; et un malaise douloureux, un malaise insoutenable crispait le coeur de Pierre. Il se disait, torturé et satisfait pourtant: 'Doit-elle souffrir en ce moment, si elle sait que je l'ai devinée!' (P\&ুJ, p. 156) 
You would have said they were spying on each other, that a state of war had just been declared between them; and a painful, an unbearable discomfort clenched Pierre's heart. He said to himself, tortured and yet satisfied: 'How she must be suffering at this moment, if she knows that I've guessed it!' [My translation]

The hermeneutic takes on a profound weight and importance.

Toujours il se demandait: 'Qu'a-t-elle pu dire à Jean? A-t-elle avoué ou a-telle nié? Que croit mon frère? Que pense-t-il d'elle, que pense-t-il de moi?' Il ne devinait pas et s'en exaspérait. Il ne leur parlait presque plus d'ailleurs, sauf devant Roland afin d'éviter ses questions. (P\&J, p. 214)

He was always asking himself: "What can she have said to Jean? Did she admit it or deny it? What does my brother believe? What does he think of her, what does he think of me?" He could not guess, and he became exasperated. Moreover, he hardly spoke to either of them any more - except in front of Roland [his father] in order to avoid his questions. [My translation]

Just such a silent war of secret observation and distrust could be seen as the basis of numerous James stories and novels. ${ }^{40}$ At the end of Pierre et Jean, very painfully, the legitimate son Pierre is expelled - like a scapegoat - from the family and France, taking up a nightmarish post as a ship's doctor, keeping always at sea so that Jean can inherit and the mother's disgrace never become known. And this precedent too seems to point to 'Paste' and Arthur's obsessive concern with the

40 And a significant difference from the earlier The Portrait of a Lady (1881), where Isabel's growing suspicion of Osmond and Madame Merle is so richly rendered, is that in Pierre et Jean and the later Jamesian cases both sides of the process are powerfully evoked. 
honour of his step-mother as drawing on the early morbid anxiety of Pierre: 'il ne pouvait hésiter, la réputation de leur mère étant menacée'; 'he couldn't hesitate, the reputation of their mother being threatened' (P\&J, p. 113). Thus while Pierre et Jean may not represent the main or predominant vein of Maupassant's achievement, which lies in the short stories, one can read 'Paste' in its light as less of a corrective to Maupassant than as a fulfilment of the trajectory he seemed to have embarked on.

iv 'une traduction libre... de Maupassant'

A possible reading of 'Paste' emerges: as a mapping of James's position, poised, or trapped, or both, between aspects of French and English literary cultures. James may be like his heroine Charlotte, caught between on the one hand the knowing Mrs Guy - whose name, as critics have noted, might associate her with that other Guy, de Maupassant: cynical, sexually preoccupied and dangerous; - and on the other hand the ghastly Arthur Prime, a specialist in implacable denial who is revealed as an unpleasant hypocrite (and as grasping, almost a thief). The symmetrical pairing of these apparent opposites for poor Charlotte is suggested by James, who marks an echo when she's with Arthur:

"Oh!" she simply sounded, as she had sounded for her last word to Mrs.

Guy; and within a minute, without more conversation, she had taken her departure. (p. 83)

Charlotte's moral sense makes her a loser, like other James characters including Fleda Vetch - and unlike Mrs Guy:

“Ah but if they're real I can't keep them!" (p. 77)

$\&$ 
"You mean to return them?"
"If I don't I'm a thief."...
"If you do you're a goose." (pp. 78-9)

James counts the cost of female idealism, in other words; though he is far from dismissing its value; but this story is not dewy-eyed about Charlotte's final situation, offers no happy ending. James is himself a critic of the optimo-normative tendency of Anglo-American literature and Charlotte's moral steadfastness certainly suffers some buffets and brings her no worldly reward (neither marriage to Arthur, escape from her ghastly job, nor possession of the pearls). To this extent the story bears out what James says about Anglo-American literary culture in the 1888 essay:

It must never be forgotten that the optimism of that literature is partly the optimism of women and of spinsters; in other words the optimism of ignorance as well as of delicacy. (LC II, p. 540)

James's alienation from 'the optimism of that literature' makes him feel French among the gallophobe English, although in fact he is also, somehow, alienated from the French spirit - stranded somewhere mid-Channel. So, certainly, he would find when his French translator Auguste Monod tried and seemingly failed to translate 'Paste' into French - 'back' into French, as James jokingly thinks of it, writing to Monod on 17 December 1905:

evidently I am in the strange predicament of defying the genius of the French language altogether, I who adore that genius, who have always found

\footnotetext{
${ }^{41}$ In The Spoils of Poynton, Mrs. Gereth twice calls Fleda Vetch, similarly a figure of self-sacrificing conscience, a 'goose' (The Spoils of Poynton, edited by David Lodge and Patricia Crick (London: Penguin Classics, 1987), pp. 177 (Ch. 17), 203 (Ch. 21)).
} 
myself irresistibly sacrificing to it, and who pass in this benighted country for an unbridled Gallicist.... I have evidently underestimated [my works'] unmanageability (irreductibility) of surface, of which your yet so comparatively mild a specimen (of the unparaphrasable) from Paste is a prompt example. Et moi qui m’imaginais que Paste se laissait lire à peu près comme une traduction libre (ou plutôt moins libre que l'original) de Maupassant... au point qu'il serait facile même de le remettre en français. ${ }^{42}$

My translation: And there I was imagining that Paste could be read almost as a free translation (or rather, less 'free' than the original) of Maupassant... to the point that it would even be easy to put it back into French.

(In fact, Monod's 'Perle Fausse' appeared in the Revue Bleue on 18 January 1908. $)^{43}$ Nothing is as easy or 'facile' as it seems with 'Paste' - just as, when the Preface says 'simply', the case and the process turn out to be anything but simple. James has so Anglicised the idea and idiom in his story that it won't go back - back in the bottle, as it were - but the story isn't quite English either. Maybe it's not Anglicised but Jacobized - translated into an idiom which is lost in translation into any other.

$42 \quad H e n r y$ James: A Life in Letters, edited by Philip Horne (London: Allen Lane, 1999), p. 431. 43 See Auguste Monod, translator, Henry James, 'Perle Fausse', Revue Blene: Revue politique et littéraire, $\mathrm{N}^{\circ} 3,5^{\circ}$ Série - Tome IX (18 janvier 1908), 73 -81. Monod's translation indeed misses, perhaps inevitably, a good deal of the nuance and particularity of James's style; but does translate back into Maupassant at one point, where 'The guest had on [NYE XVI, p. 336: 'displayed'] a lovely necklace and had apparently not lost her habit of overflowing with the pride of such ornaments' (p. 83) becomes 'L'invitée portait un ravissant collier et paraissait aussi satisfaite que jamais d'elle même et de sa parure' (p. 80; my emphasis). 
At the very end of 'Paste' James offers us a twist - like one of Maupassant's own in the short stories. Mrs Guy has said she saw and bought the pearls in the shop window only 'by miraculous luck'.

Charlotte felt really morbid too after they had separated and she found herself full of thought. She even went the length of asking herself what sort of a bargain Mrs. Guy had driven and whether the marvel of the recognition in Bond Street had been a veracious account of the matter. Hadn't she perhaps in truth dealt with Arthur directly? It came back to Charlotte almost luridly that she had had his address. (p. 84) ${ }^{44}$

This is the twist, a turn of the screw. She suspects that Mrs Guy too has lied - that she has gone direct to Arthur. There's a perverse alliance of opposites emblematised in the deal struck between Arthur and Mrs Guy - as if between French cynicism and English prurience other more human and decent possibilities were being sold short or ruled out. In opposition is true friendship, as Blake says. And what was the deal 'dealt'? Bond Street at the very start of The Golden Bowl, we may remember, is a place not only of expensive leisure consumption (art, jewellery, clothes) but of sexual potentiality - of 'possibilities in faces'. ${ }^{45}$ And maybe 'asking herself what sort of a bargain Mrs. Guy had driven' and 'almost luridly' here suggest together that the transaction may or may not have been purely financial Mrs Guy seems sexy and predatory, capable de tout, and Arthur has seemed to have sex as well as respectability morbidly on the brain. The pearls may once again have changed hands as a result of some dodgy relationship, or act - in a mini-La Ronde? - as if James were flirting, even in the Christmas number of Frank Leslie's Popular

44 In the NYE, 'Charlotte felt really morbid' becomes 'the young person employed in Eaton Square felt really morbid' (XVI, p. 337). The revised formula may remind us that a mansion in Eaton Square is where a few years later another Charlotte, originally 'sent for' to help (p.168), ends up as the mistress, married to the millionaire Adam Verver in The Golden Bowl. 45 The Golden Bowl, p.27. 
Monthly, with a darkly improper Maupassant ending. After all, James's writing has come to a remarkable sensual life in its description of the pearls, and of the bodies they touch, the bodies which emit or secrete words which refer to them. Thus, strikingly, Mrs Guy, wearing the necklace in triumph, speaks a body-language that her mouth renders in parallel terms:

This lady's white shoulders heaved, under the pearls, with an emotion that the very red lips which formed, as if for the full effect, the happiest opposition of colour, were not slow to translate. (p. 78)

Charlotte learns to wonder in a worldly way - like the heroine of 'The Story in It' in 1902 - with a French freedom of imagination, but an English innocence of conduct. This hardly attenuates the hardships of her life in servitude at Bleet or in Eaton Square, however. Charlotte's poverty may represent freedom, may allow her space to cherish finer feelings in secret; but her defeat is bitter.

That darkly cynical implication - if we choose to take it - balances or matches a more poetic, or sentimental, one that I have touched on already - one implicit in the unemphasised fact that the never-seen figure at the heart of the story, the vicar's wife, has died so short a time after her husband, a fortnight later - as if for love. The story starts with Charlotte noting Arthur's manner 'within a week of his stepmother's death, within three of his father's' (p. 63). We might recall that in a sense the central character of the story is a woman even more eclipsed than Charlotte - 'the late Mrs. Prime... — the effaced Miss Bradshaw'. This former actress, referred to as a 'provincial Ophelia', the only first name we ever get for her, may be thought to die from the loss of her husband - from love, like the Shakespearian heroine. Unless, less inspiringly, it's that they both perished from the same infectious bug. 
This possible romantic story between the vicar and the actress - of lost passion, of redemptive affection and fidelity - is seen neither by Arthur nor Mrs Guy. Whatever the truth of the pearls and their value, and the passion they seem to speak of, it seems to have been the force of her love for her husband that has ended her life - a moral, with its stirring possibilities, missed by all but the humble, imaginative Charlotte.

We might recall, in conclusion, thinking of dead women and unappreciated pearls, the way the image of the pearl is associated with Milly Theale in the second half of The Wings of the Dove a couple of years later - and in the final chapter comes to characterise Milly's beautiful last gesture in her letter and the possibilities of the turn she might have given it: Densher's imagination

had made of them a revelation the loss of which was like the sight of a priceless pearl cast before his eyes—-his pledge given not to save it—into the fathomless sea, or rather even it was like the sacrifice of something sentient and throbbing, something that, for the spiritual ear, might have been audible as a faint far wail. ${ }^{46}$

The unwritten - or the unread - is again the pearl. And this collocation of 'pearl' and 'cast' and 'before' recalls the Gospel - Matthew 7:6:

Give not that which is holy unto the dogs, neither cast ye your pearls before swine, lest they trample them under their feet, and turn again and rend you. (King James Version) 
Charlotte in 'Paste' has cast her pearls before swine, we might say, and the swine especially Arthur - have not only trampled them but turned on ber and rent her. James can share, that is, Maupassant's 'vision of ugliness' - but satisfies too another sense, that of 'the spiritual ear', finding a beauty in the revelation of a sacrifice - a tribute, though perhaps a futile one, to something higher.

\section{BIBLIOGRAPHY}

Anon., 'Police', The Times, London, Thursday, 2 May 1889, p. 3.

Boyington, Mary, “Esprit de Maupassant”: Henry James and French Realism, A Re-evaluation' (PhD thesis, Aix-Marseille Université, 2017).

Child, Theodore, 'Literary Paris. Second Paper', Harper's New Monthly Magazine (September 1892), 85.508, 489-507.

Delbaere-Garant, Jeanne, Henry James: the Vision of France, Paris: Société d'Editions (Les Belles Lettres), 1970 (Series Bibliothèque de la Faculté de philosophie et lettres de l'Université de Liège; fasc.191).

Edel, Leon, Henry James: A Biography: The Middle Years, 1884-1894 (London: HartDavis, 1963).

Edel, Leon, \& Adeline Tintner, The Library of Henry James (Ann Arbor, MI: UMI Research Press, 1987).

Freud, Sigmund, 'The Antithetical Meaning of Primal Words' (1910), The Standard Edition of the Complete Psychological Works of Sigmund Frend: Five Lectures on PsychoAnalysis, Leonardo da Vinci and Other Works, (London; Hogarth Press, 1953-74), 24 vols, Volume XI, 153-162.

Fusco, Richard, Maupassant and the American Short Story: The Influence of Form at the Turn of the Century (University Park, PA: Penn State UP, 1994).

Garnier, Marie-Reine, Henry James et la France, Paris: H. Champion, 1927. 
Graves, Charles Larcom, Mr. Punch's History of Modern England: Vol. 1: 1841-1857 (London: Cassell \& Co., 1921), 4 vols.

T.W. Higginson, 'Emily Dickinson's Letters', Atlantic Monthly (October 1891), LXVIII, 444-56.

Horne, Philip, 'The Lessons of Flaubert: James and L'Education Sentimentale', The Yearbook of English Studies 1996: Strategies of Reading: Dickens and After, Vol. 26, edited by Nicola Bradbury, 154-162.

Philip Horne, "Where are our moral foundations?” - Emily Dickinson and Henry James', in Studies in Victorian and Modern Literature: A Tribute to John Sutherland, ed. William Baker (Fairleigh Dickinson University Press, 2015), 243-261.

James, Henry, The Ambassadors, edited by Adrian Poole, (London: Penguin Classics, 2008).

James, Henry, "The Author of "Beltraffio"”, Stories Revived: First Series (London: Macmillan 1885), 1-70.

James, Henry, 'The Bench of Desolation', Putnam's Magazine (October-December 1909; January 1910), 56-62; 151-60; 297-303; 487-94.

James, Henry, The Bostonians, ed. Richard Lansdown (London: Penguin Classics, 2000).

James, Henry, 'Flickerbridge', The Better Sort (London: Methuen, 1903), 105-122. James, Henry, The Golden Bowl, ed. Ruth Bernard Yeazell (Penguin Classics, 2009). James, Henry, 'Guy de Maupassant' (1888); ‘Guy de Maupassant' (1889), Literary Criticism: French Writers, Other European Writers, The Prefaces to the New York Edition, edited by Leon Edel and Mark Wilson (New York: Library of America, 1984), 52149; 549-54.

The Complete Notebooks of Henry James, edited by Leon Edel and Lyall H. Powers (New York: Oxford University Press, 1987).

Henry James Letters, edited by Leon Edel (Cambridge, MA: Belknap Press, 1974-84), 4 vols.

Henry James: A Life in Letters edited by Philip Horne (London: Allen Lane, 1999). 
James, Henry, Literary Criticism: French Writers, Other European Writers, The Prefaces to the New York Edition, edited by Leon Edel and Mark Wilson (New York: Library of America, 1984).

James, Henry, 'A New England Winter', Tales of Three Cities (London: Macmillan 1884), 131-208.

James, Henry, 'On the Occasion of Hedda Gabler', Essays in London and Elsewhere (London 1893), 241-47.

James, Henry, 'Paste', Frank Leslie's Popular Monthly (December 1899), XLIX, 17589.

James, Henry, 'Paste', The Soft Side (London: Methuen, 1900), 63-84. James, Henry, 'Paste', The New York Edition of the Novels and Tales of Henry James, 24 vols (1907-9; New York: Scribner, 1908), XVI, 315-37. James, Henry, translated by Auguste Monod, 'Perle Fausse', Revue Blene: Revue politique et littéraire, № 3, 5º Série - Tome IX (18 janvier 1908), 73 -81. James, Henry, 'Preface to The Author of 'Beltraffio" etc.' (New York Edition, Vol. XVI), Literary Criticism: French Writers, Other European Writers, The Prefaces to the New York Edition, edited by Leon Edel and Mark Wilson (New York: Library of America, 1984), 1238-45.

Selected Letters of Henry James to Edmund Gosse: A Literary Friendship, edited by Rayburn S. Moore (Baton Rouge and London: Louisiana State University Press, 1988).

James, Henry, The Spoils of Poynton, edited by David Lodge and Patricia Crick (London: Penguin Classics, 1987).

James, Henry, 'The Story in It', Anglo-American Magazine (January 1902), VII, 1-13. James, Henry, The Wings of the Dove, edited by Millicent Bell (London: Penguin Classics, 2008).

Maupassant, Guy de, 'Les Bijoux'; 'La Parure’; Contes et Nouvelles, ed. Louis Forestier (Paris: Gallimard: Bibliothèque de la Pléiade, 1974 \& 1979), 2 vols, I, $764-$ 71; I, 876-95; I, 1198-1206; II, 314-8. 
Maupassant, Guy de, Pierre et Jean, ed. Bernard Pingaud (Paris: Folio Classique, 1982; repr. 2012; includes 'Le Roman').

Maupassant, Guy de, Une Vie, edited by Pierre Cogny (Paris: Garnier-Flammarion, 1974).

Satiat, Nadine, Maupassant (Paris: Flammarion, 2003).

Savoy, Eric, 'France, French, and the French' (review of Peter Brooks, Henry James Goes to Paris), Henry James Review, Vol. 30, No. 2, Spring 2009, 196-206.

Segnitz, T.M., "The Actual Genesis of Henry James's "Paste", American Literature Vol. 36, No. 2, May 1964, 216-219.

Sturges, Jonathan (translator), The Odd Number: Tbirteen Tales by Guy de Maupassant, with an Introduction by Henry James (New York: Harper \& Brothers, 1889).

The Times (London, England), Thursday, May 02, 1889; p. 3.

Tolstoy, Leo, 'The Works of Guy de Maupassant' (1894) (translated by Leo

Wiener, 1905), The Complete Works of Count Tolstoy (London: J.M. Dent, 1920), 24 vols, XX: consulted 25 August 2018 at

\section{https://en.wikisource.org/wiki/The Works of Guy de Maupassant}

Tredy, Dennis F., "Teaching the "Grandsons of Balzac" a Lesson: Henry James in the 1890's' (E-rea: Revue électronique d'études sur le monde Anglophone, 2.1 (2004)) [mis en ligne le 15 juin 2004, consulté le 17 septembre 2016].

Nathaniel Parker Willis, Dying to Keep Him; Or, Tortesa the Usurer, (London: Hugh Cunningham, 1839).

Wordsworth, William, 'Lines (Written a few miles above Tintern Abbey)' (1798), William Wordsworth and Samuel Taylor Coleridge, Lyrical Ballads: second edition, edited by Michael Mason (London: Longman, 2007.

\section{Archives}

James to Theodore Child, unpublished MS letter (Virginia MSS 6251-C (Box 2, \#135)) 
Unpublished MS letters to James Brand Pinker, 7 August 1899 \& 2 September 1899 (Beinecke, Za James 1, Vol. 1). 